10 Teuscher A, Berger WG. Hypoglycaemia unawareness in diabetics transferred to human insulin. Lancet 1987;ii:382-5.

11 Berger W, Keller U, Honegger B, Jaeggi E. Warning symptoms of hypoglycaemia during treatment with human and porcine insulin in diabetes mellitus. Lancet 1989;:1041-4.

12 Egger M, Davey Smith G, Imhoof H, Teuscher A. Risk of severe hypoglycaemia in insulin treated diabetic patients transferred to human insulin a case control study. BMF 1991;303:617-21.

13 Egger M, Davey Smith G, Teuscher AU, Teuscher A. Influence of human insulin on symptoms and awareness of hypoglycaemia: a randomised double blind crossover trial. BMF 1991;303:622-6.

14 Mann NP, Johnston DI, Reeves WG, Murphy MA. Human insulin and porcine insulin in the treatment of diabetic children: comparison of metabolic control and insulin antibody production. BMf 1983;387:1580-2.

15 Home PD, Mann NP, Hutchison NS, Park R, Walford S, Murphy M, et al. A fifteen month double-blind cross-over trial of the efficacy and antigenicity of human and pork insulins. Diabetic Med 1984; i:93-8.

16 DCCT Research Group. Epidemiology of severe hypoglycemia in the Diabetes Control and Complications Trial. Am f Med 1991;90:450-4.

17 Gerich JE, Langlois M, Noacco C, Karam JH, Forsham PH. Lack of glucagon response to hypoglycemia in diabetes: evidence for an intrinsic pancreatic alpha cell defect. Science 1973;182:171-3.

18 Amiel SA, Tamborlane WV, Simonson DC, Sherwin RS. Defective counter regulation after strict glycemic control of insulin-dependent diabetes mellitus. N Engl f Med 1987;316:1376-83.

19 Bolli G, De Feo P, Compagnucci P, Cartechini MG, Angeletti G, Santeusanio $\mathrm{F}$, et al. Abnormal glucose counterregulation in insulin-dependent diabetes mellitus. Interaction of anti-insulin antibodies and impaired glucagon and epinephrine secretion. Diabetes 1983;32:134-41.

20 Heller SR, MacDonald IA, Herbert M, Tattersall RB. Influence of sympathetic nervous system on hypoglycaemic warning symptoms. Lancet 1987;ii: 359-63.

21 Schlüter KJ, Petersen KG, Sontheimer J, Enzmann F, Kerp L. Differen counterregulatory responses to human insulin (recombinant DNA) and purified pork insulin. Diabetes Care 1982;5 (suppl 2):78-81.

22 Rosak C, Althoff P-H, Enzmann F, Schoffling K. Comparative studies in intermediary metabolism and hormonal counter-regulation following human insulin (recombinant DNA) and purified pork insulin in man. Diabetes Car 1982;5(suppl 2):82-9.

23 Landgraf-Leurs MMC, Bruegelmann I, Kammerer S, Lorenz R, Landgraf R. Counterregulatory hormone release after human and porcine insulin in healthy subjects and patients with pituitary disorders. Klin Wochensch 1984;62:659-68.

24 Berger $M$. Human insulin: much ado about hypoglycaemia (un)awareness. Diabetologia 1987;30:829-33.

25 Owens DR, Vora JP, Tronier B, Keller U, Luzio S, Turkes A. Hormonal counterregulatory responses to human (semi-synthetic and recombinant DNA) and porcine insulin induced hypoglycaemia. Diabetes Res 1988;8: $17-20$

26 Heine RJ, van der Heyden EAP, van der Veen EA. Responses to human and porcince insulin in healthy subjects. Lancet 1989;ii:946-9.

27 Kern W, Born J, Kerner W, Fehm HL. Counter-regulatory hormone responses to human and porcine insulin in healthy subjects. Lance 1989;ii:485.

28 Haupt E, Galle $M$, Oerter E. Symptoms of hypoglycaemia and counterregulatory effects with human and animal insulins. In: Federlin $\mathrm{K}, \mathrm{Keen} \mathrm{H}$ Mehnert $\mathrm{H}$, eds. Hypoglycaemia and human insulin. Stuttgart: Georg Thiem Verlag, 1991:119.

29 Fisher BM, Gray CE, Beastall GH, Frier BM. Responses to acute insulin induced hypoglycaemia in diabetic patients: a comparison of short-actin human and porcine insulins. Diabetes Res 1988;8:1-8.

30 Siöbom NC, Lins P-E, Adamson U, Theodorsson E. A comparative study on the hormonal responses to insulin-induced hypoglycaemia using semi- synthetic human insulin and pork insulin in patients with type 1 diabetes mellitus Diabetic Med 1990;7:775-9.

31 Bendtson I, Binder C. Counterregulatory hormonal response to insulin induced hypoglycaemia in insulin-dependent diabetic patients: a comparison of equimolar amounts of porcine and semisynthetic human insulin. $\mathcal{F}$ Interm Med 1991;229:293-6.

32 Patrick AW, Bodmer CW, Tieszen KL, White MC, Williams G. Human insulin and awareness of acute hypoglycaemic symptoms in insulin dependent diabetes. Lancet 1991;338:528-32.

33 Maran A, MacDonald IA, Amiel SA. The euglycemic-hypoglycemic clamp-a reliable tool for the investigation of responses to hypoglycemia [Abstract]? Diabetes 1991;40:544a.

34 Egger M, Davey Smith G, Teuscher A. Hypoglycaemia awareness and human insulin. Lancet 1991;ii:950.

35 Spraul M, Sonnenberg GE, Reck-Linnenberg M, Urbanek C, Berger M. Kein Unterschied in der hormonellen Gegenregulation nach Hypoglykämie durch Schweine-oder Humaninsulin bei stoffwechselgesunden Probanden. durch Schweine-oder Humaninsulin bei stoffwechselges

36 Rothmann KJ. No adjustments are needed for multiple comparisons. Epidemiology 1990;1:43-6.

37 Tattersall RB, MacDonald IA. Human insulin. BMF 1989;299:1339.

38 Redmond S. Changing to human insulin. Balance 1988;Aug/Sept:66-7.

39 Hepburn DA, Eadington DW, Patrick AW, Colledge NR, Frier BM Symptomatic awareness of hypoglycaemia: does it change on transfer from animal to human insulin? Diabetic Med 1989;6:586-90.

40 Duncan C, Campbell IW, McBain AM, Jones IG. Hypoglycaemia survey in insulin-dependent diabetic population at time of change from beef to human insulin. Practical Diabetes 1990;7:18-9.

41 Stocks AE. Human insulin. Med f Aust 1991;154:295-6.

42 Egger M, Teuscher A. Symptomatic awareness of hypoglycaemia: does it change on transfer from animal to human insulin? Diabetic Med 1990;7:269.

43 Hepburn DA, Frier BM. Hypoglycaemic unawareness and human insulin. Lancet 1989; $1: 1394$.

44 Patrick AW, Williams G. Human insulin. BMf 1991;303:1266.

45 Egger M, Davey Smith G, Teuscher A. Human insulin. BMJ 1991;303: 1267-8.

46 Frier BM, MacLeod KM, Hepburn DA. Human insulin. BMF 1991;303 1266-7.

47 DCCT Research Group. The diabetes control and complications trial (DCCT) Design and methodologic considerations for the feasibility phase. Diabetes 1986;35:530-45.

48 Gorden PH. Human insulin and hypoglycemia. N Engl f Med 1990;322: 1007-8.

49 Anon. Hypoglycaemia and diabetes control. Lancet 1991;338:853-5.

50 Orchard TJ, Maser RE, Becker DJ, Donnan JS, Drash AL. Human insulin use and hypoglycemia: insights from the Pittsburgh epidemiology of diabetes complications study. Diabetic Med 1991;8:469-74.

51 Tattersall RB, Gill GV. Unexplained deaths of type 1 diabetes under age 50 Diabetic Med 1991;8:49-58.

$52 \mathrm{Karem} \mathrm{JH}$. Hormonal responses to human and pork insulin. Clinical Diabete 1991;Nov/Dec:94-5.

53 Stephenson J, Fuller J. Hypoglycaemia as a cause of death in human insulin era. Lancet 1990;335:661.

54 Heine RJ, van der Veen EA. Human insulin and hypoglycaemia. Lance $1990 ; \mathrm{i}: 62$.

55 Teuscher A, Diem P. Do fully synthetic and genetically synthesised human insulins differ? Lancet 1980;ii: 1186 .

56 Keen H, Jarrett J. Management of diabetes. Medicine International 1981; 1 330-3.

57 Egger M, Teuscher A, Berger W. Hypoglycaemia (un)awareness: human vs animal insulin. Diabetologia 1988;31:453-4.

58 No funding for definitive insulin study. Scrip 1992;7 February:22.

\title{
Human insulin and hypoglycaemia: burning issue or hot air?
}

\author{
Gareth Williams, Alan W Patrick
}

Does the use of human sequence insulin prevent diabetic patients from perceiving hypoglycaemic symptoms, and does it increase the risk of severe hypoglycaemia?

These questions were first raised five years $\mathrm{ago}^{1}$ and continue to trouble those involved with diabetes. The issue is difficult to resolve because the suspected adverse effects of human insulin - that is, reduced awareness of hypoglycaemia and increased rate of severe episodes - are inextricably woven into the fabric of insulin treatment. Despite many patients' claims the ability to estimate the prevailing blood glucose concentration is notoriously poor ${ }^{2}$; for example, even educated and motivated patients who took part in a recent study of hypoglycaemia wrongly judged themselves to be hypoglycaemic in a quarter of episodes. ${ }^{3}$ Perception of hypoglycaemia can be dulled by many factors, including alcohol and various drugs. Moreover, for reasons which remain obscure, many patients with longstanding diabetes lose awareness of the onset of hypoglycaemia and may rapidly develop neuro- glycopenic features (for example, confusion, aggression, and coma) before any recognisable sympathetically mediated symptoms such as sweating and tremor. This occurs irrespective of the insulin species used and was well recognised long before the advent of human insulin. ${ }^{4}$

Hypoglycaemia is an inevitable consequence of the narrow therapeutic ratio of insulin and is a common complication of treatment of diabetes: each year one in seven insulin dependent diabetic patients will have a hypoglycaemic episode severe enough to cause unconsciousness or require help from others. A specific effect of human insulin is all the harder to detect against this noisy background because its introduction during the 1980s generally coincided with greater efforts to tighten glycaemic control by intensifying insulin treatment, which itself may make hypoglycaemia more frequent. ${ }^{6}$ This important confounding factor, also not related to insulin species, is highlighted by the $68 \%$ increase in the frequency of severe hypoglycaemia observed in diabetic children in Bern

Dr Williams. 
between 1984 and 1988.' This rise paralleled the increasing use of human insulin but occurred equally in patients receiving human or animal insulins; interestingly,.a similar rise in the background rate of hypoglycaemia could explain most of the excess episodes attributed to the use of human insulin in adults in the same region. ${ }^{8}$

To find a solution to this vexed issue and to limit the medical and social damage in the interim, several theoretical and practical questions must be addressed.

\section{How could human insulin alter the awareness of hypoglycaemia?}

Human and porcine insulins differ in only one out of 51 amino acid residues; although apparently trivial, this change evidently affects the physicochemical and pharmacokinetic properties of the molecule, as porcine insulin is more lipophilic than human insulin. Subcutaneously injected human insulin is absorbed slightly faster than porcine insulin, at least under laboratory conditions, but this relatively minor difference could easily be swallowed up in real life by the immense and unpredictable variability in insulin absorption. ${ }^{9}$ Intriguingly, insulin may exert direct effects on the brain, and these may differ between various insulin species. Animal studies suggest that insulin does not respect the concept of the blood-brain barrier and can enter the cerebrospinal fluid from the circulation, albeit slowly. ${ }^{10}$ Insulin receptors are found in several brain regions, including the hypothalamus, which triggers the neuroendocrine responses to hypoglycaemia. ${ }^{11}$ The more lipophilic porcine insulin could gain access to the brain more readily and, in theory, could modulate the effects of low glucose concentrations on hypothalamic or other neurones. A direct effect of insulin on the human brain is suggested by the recent demonstrations that counterregulatory hormone responses and symptoms differ when comparable hypoglycaemia is induced by high or low insulin concentrations, ${ }^{12}{ }^{13}$ and it has also been shown that porcine and human insulins have differential effects on cortical auditory evoked potentials during hypoglycaemia. ${ }^{14}$ This exciting area deserves further research.

\section{How should future studies be designed?}

Two separate hypotheses must be tested-namely, that the use of human insulin $(a)$ impairs the perception of hypoglycaemic symptoms and $(b)$ increases the frequency of severe hypoglycaemic episodes. The first is scientifically interesting and may clarify the direct effects of insulin on the brain, but it is the second which is of vital importance to diabetic people. Any future studies must aim specifically at testing one or both of these hypotheses and must be powerful enough to do this; neglect of this basic principle has invalidated several previous studies.

The literature includes anecdotes and case reports, laboratory studies, and retrospective and prospective surveys, which have been performed in diabetic or non-diabetic subjects with widely variable selection criteria. The enthusiasm with which the various groups have attacked their opponents' work (for example, references 16 and 17) forces us to conclude that none of the published studies-including our own $^{15}$ - can be regarded as definitive. None the less, previous work has been useful in identifying important pitfalls which must be avoided in future.

Because of general awareness of the debate and (regrettably) the possible motive of compensation claims insulin species can now be compared only under at least single blind conditions. "One off" laboratory studies may not be powerful enough to detect a genuine effect of insulin species because individual symptomatic and neuroendocrine responses to hypoglycaemia are so variable; repeated studies would compress the error bars and placate the statisticians but would be unacceptable to subjects and ethics committees alike. The hypothesis that human insulin increases the frequency of severe hypoglycaemic episodes can be tested only in field studies, and this is probably the only setting which will carry credibility for diabetic patients. All the subjects from our own laboratory study, ${ }^{15}$ which failed to show any significant differences between human and porcine insulins, remain convinced that human insulin interferes with awareness of hypoglycaemia and have chosen to be treated with animal insulins.

Selection of subjects is also crucial. We argue that studies should concentrate on insulin dependent diabetic patients who claim to have reduced awareness of hypoglycaemia and more frequent hypoglycaemic episodes during human insulin treatment, and who have reported that awareness returned when transferred back to animal insulin. Such selection would greatly increase the power of the study and reduce the number of patients required (which is probably several hundred for an unselected population), although the rarity of suitable patients, at least in Merseyside,${ }^{15}$ may demand a multicentre survey. No doubt the statisticians, who have been vocal in the debate so far, will be able to give precise details of the necessary size and duration of such a study.

Two recent studies fulfil many of these essential criteria. The first, conducted in Australia, was a double blind, crossover field comparison of four one month treatment periods (two with human insulin and two with porcine insulin, in random order) in 50 patients selected as above..$^{18}$ No significant differences in the nature or frequency of hypoglycaemic episodes were found between the two insulins, and only two patientsfewer than would be predicted by chance alonecorrectly guessed the sequence of insulin species. The second study, ${ }^{19}$ from groups in London and Nottingham, was published only in abstract form at the time of writing. This study also found no differences in the characteristics of hypoglycaemia between the two insulin species in 17 similarly selected patients who were treated double blind for two months with each species. Furthermore, detailed hypoglycaemic clamp studies performed with the same insulin species at the end of each treatment period did not disclose any significant differences between them in the endocrine, symptomatic, or psychomotor changes during hypoglycaemia. The full paper is awaited with interest.

\section{What should be done in the interim?}

In our opinion the balance of available evidence does not suggest that human insulin specifically impairs perception of hypoglycaemic symptoms or that its use predisposes to severe hypoglycaemia. Irrespective of whether we are right or wrong, we have a duty of care to help our diabetic patients to live with a difficult and demanding disease. The wishes of the patient must therefore be respected. Accordingly, we have no hesitation in transferring patients back to animal insulins if they so wish, although all the usual precipitants of hypoglycaemia (especially mismatching of insulin, food and exercise, and alcohol and drugs) must also be sought and excluded if possible. Hypoglycaemia is the main fear of most insulin dependent diabetic people and often overshadows the threat of long term complications; if any good emerges from the current unpleasantness it will be to remind everyone that diabetes is an important medical and social problem and to emphasise that doctors must take hypoglycaemia seriously. 
Diabetes is a complicated disease which demands close cooperation between the patient and the diabetes care team and, as such, is totally unsuited to the practice of defensive medicine. It is therefore unfortunate that the human insulin issue may result in litigation, perhaps against those who prescribe insulin as well as the drug companies which manufacture it. This is another compelling reason for trying to resolve the scientific debate as rapidly as possible.

\section{Future strategy}

Both sides of the human insulin debate were recently represented at a well attended symposium in Liverpool..$^{20}$ Some rapprochement occurred in that previous studies and their limitations were discussed, generally in a constructive spirit. A series of suggestions emerged, which seem sensible guidelines for the present (box).

1 Teuscher A, Berger W/G. Hypoglycaemia unawareness in diabetics transferred from beef/porcine to human insulin. Lancet 1987;ii:382-5.

2 Cox DJ, Gonder-Frederick L, Julian D. Intensive versus standard blood glucose awareness training (BGAT) with insulin-dependent diabetes: glucose awareness training (BGAT) with insulin-dependent

3 Egger M, Smith GD, Teuscher AU, Teuscher A. Influence of human insulin on symptoms and awareness of hypoglycaemia: a randomised double blind crossover trial. $B M F$ 1991:303:622-6.

4 Gerich JE, Mokan M, Veneman T, Korytkowski M, Mitrakou A. Hypoglycemia unawareness. Endocr Rev 1991;12:356-71.

5 Lawrence RD. Isulin hypoglycaemia. Changes in nervous manifestations. Lancel 1941;ii:602.

6 Gale EAM. Hypoglycaemia and human insulin. Lancet 1989;ii:1264-6.

7 Egger $M$, Gschwend S, Smith GD, Zuppinger K. Increasing incidence of hypoglycaemic coma in children with IDDM. Diabetes Care 1991;14 $1001-5$.

8 Egger M, Smith GD, Imhoof H, Teuscher A. Risk of severe hypoglycaemia in insulin treated diabetic patients transferred to human insulin: a case-contro study. BMF 1991;303:617-21.

9 Linde B. The pharmacokinetics of insulin. In: Pickup JC, Williams G, eds. Textbook of diabetes. Oxford, Blackwell Scientific, 1991:371-83.

10 Schwartz M, Sipols A, Kahn S, Latteman D, Taborsky G, Bergman R, et al. Kinetics and specificity of insulin uptake from plasma into cerebrospinal fluid Am f Physiol 1990;259:E378-83.

11 Corp E, Woods SC, Porte D, Dorsa D, Figlewicz D, Baskin D. Localization of insulin binding sites in the rat hypothalamus by quantitative autoradiography. Neurosci Lett 1986;79:17-22.

\section{Suggested strategy for managing diabetic patients with insulin}

(1) Patients who are satisfactorily treated with animal insulin should not be transferred routinely to human insulin. If transfer is indicated on medical grounds (for example, hypersensitivity to animal insulins) the doctor should discuss this fully with the patient and monitor the change over carefully. It is not acceptable for patients to be transferred to human insulin by pharmacists

(2) Patients receiving human insulin should be transferred back to animal insulin if they so wish

3) Animal insulin preparations must therefore remain available, they should include cartridges for the pen injection devices which are increasingly popular with patients (only human insulin cartridges are available for the most widely used devices)

(4) Adequately designed studies should be performed as a matter of urgency to determine conclusively whether human insulin has specific adverse effects

12 Diamond M, Hallarman L, Starick-Zych K, Jones T, Connolly-Howard M, Tamborlane W, et al. Suppression of counterregulatory response to hypoglycaemia by insulin per se. J Clin Endocrinol Metab 1991;72:1388-90.

13 Kerr D, Reza M, Smith N, Leatherdale BA. Importance of insulin in subjective, cognitive and hormonal responses to hypoglycemia in patients with IDDM. Diabetes 1991;40:1057-62.

14 Kern W, Lieb K, Kerner W, Born J, Fehm HL. Differential effects of human and pork insulin-induced hypoglycemia on neuronal function in humans. Diabetes 1990;39:1091-8.

15 Patrick AW, Bodmer CW, Tieszen KL, White MC, Williams G. Human insulin and awareness of acute hypoglycaemic symptoms in insulindependent diabetes. Lancet 1991;338:528-32.

16 Correspondence. Human insulin. BMJ 1991;303:1265-8.

17 Correspondence. Hypoglycaemia awareness and human insulin. Lancet 1991;338:950-1.

18 Colagiuri S, Miller JJ, Petocz P. Double-blind crossover comparison of human and porcine insulins in patients reporting lack of hypoglycaemia awareness. and porcine insulins in 19

19 Maran A. Macdonald IA, Gale EAM, Amiel SA. Human insulin does not affect the presentation of hypoglycaemia in type 1 diabetes: a clinical and the presentation of hypoglycaemia in type 1 diabetes: a
laboratory study (abstract). Diabetic Med 1992;9 (suppl 1):11A.

20 Patrick AW, Williams G. The Liverpool symposium on human insulin and hypoglycaemia. Diabetic Med 1992;9:579-80.
Is there any evidence that pierced ears are a source of infection, and are there any European Community regulations governing the sale of earrings for pierced ears?

There are several aspects to this inquiry. Ear piercing does carry a risk of infection. In 1983 European Community (EC) directives were issued under the Local Government Miscellaneous Provisions Act 1982, which required the registration of people undertaking ear piercing in England and Wales. The directive specified that there should be no risk of transmitted infection. Manufacturers redesigned their ear piercing equipment, and several "gun" systems are now available which use presterilised ear studs and back clasps. In 1987 the Department of Health and Social Security issued a guidance for piercers, which recommended the use of these "gun" systems. Interestingly, there seem to be no EC regulations on this matter.

Once an epithelialised sinus has been created by ear piercing it is unlikely to be broached by micro-organisms, but inflammatory changes around the piercing site are commonly observed. These changes are usually traumatic in origin and may be caused by the person fiddling with the earring or wearing excessively heavy earrings. Sometimes inflammation may arise from wearing earrings in windy conditions or during vigorous exercise. Such inflammation may be accompanied by swelling of the sebaceous glands in the ear lobe. Unless this traumatic inflammation is complicated by infection treatment is not required and the problem usually settles with rest.

Contact dermatitis caused by earrings is also common. There is a significant correlation between ear piercing and the development of nickel sensitivity. 'Piercing studs are usually gold plated stainless steel, and although the steel does contain nickel it is usually well complexed and relatively non-allergic. EC regulations do exist on this matter and specify a minimum of a $12 \mu \mathrm{m}$ plating of gold. The act of piercing is unlikely to be responsible for the nickel sensitivity, which probably arises from subsequent exposure to earrings containing nickel. Once eczema occurs it can become infected. In my experience patients suffering this are often persistent carriers of staphylococci. Although the infected eczema will usually respond rapidly to a steroid-antibiotic combination, the problem will recur unless the wearing of earrings containing nickel is avoided.

Other recognised complications of ear piercing include the development of dumb bell keloids and granuloma, bu such complications are not generally associated with infection. $-\mathrm{R}$ D ALDRIDGE, senior lecturer and honorary consultant dermatologist, Edinburgh

Van Hoogstraten IMW, Andersen KE, von Blomberg BME, Boden D, Bruynzeel DP, Burrows D, et al. Preliminary results of a multicentre study on the incidence of nickel allergy in relationship to previous oral and cutaneous contacts. In: Frosh PJ, Dooms-Goossens A, Lachapelle J-M, Rycroft RJG, Scheper RJ, eds. Current topics in contact dermatitis. Amsterdam: Springer-Verlag, 1989:178-83. 